\title{
Drug-induced oral lichenoid reactions. A literature review
}

\author{
P Serrano-Sánchez ${ }^{1}$, JV Bagán ${ }^{2}$, Jiménez-Soriano ${ }^{3}$, G Sarrión ${ }^{1}$ \\ ${ }^{1}$ Dental surgeon. Postgraduate in Medicine and Oral Surgery. Faculty of Medicine and Dentistry, University of Valencia. Service \\ of Stomatology, Valencia University General Hospital. Valencia, Spain \\ ${ }^{2}$ DDS, PhD Chairman of Oral Medicine, University of Valencia. Head of the Service of Stomatology. Valencia University Gene- \\ ral Hospital. dValencia, Spain. \\ ${ }^{3} \mathrm{DDS}$, PhD Professor of Oral Medicine. University of Valencia. Valencia. Spain.
}

\author{
Correspondence: \\ Hospital General Universitario \\ Servicio de Estomatología \\ Avda. Tres Cruces $s / n$ \\ 46014 - Valencia (Spain) \\ dr.serranosanchez@gmail.com
}

Received: $15 / 02 / 2010$

Accepted: $21 / 03 / 2010$

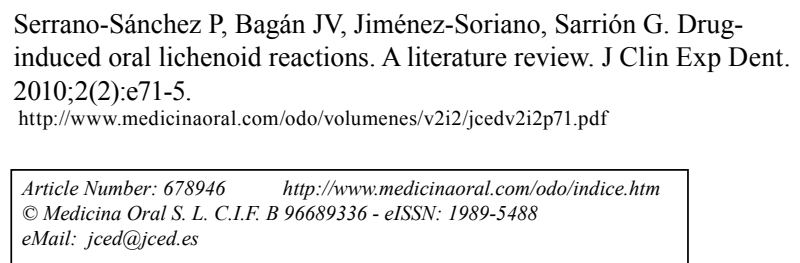

\begin{abstract}
The terms oral lichenoid reactions or oral lichenoid lesions refer to lesions histologically and clinically similar to oral lichen planus, though with the particularity that in these cases the underlying cause is identifiable. In addition, these lesions are described according to the causal factor involved, including alterations resulting from direct contact with dental restoration materials, drug-related lesions, and lesions associated to graft-versus-host disease.

Drug-induced oral lichenoid reactions or oral lichenoid lesions were first cited in 1971 by Almeyda and Levantine. Since then, many drug substances have been associated with such lesions. The most common agents are nonsteroidal antiinflammatory drugs and angiotensin converting enzyme inhibitors.
\end{abstract}

Key words: Oral lichenoid reactions, oral lichenoid lesions, drugs, medicines, drug-induced oral lesions. 


\begin{tabular}{|c|c|c|c|c|}
\hline Drug groups & Drug & Reference & No. cases & Histology \\
\hline \multirow[t]{11}{*}{ Antihypertensive } & Methyldopa & Stevenson (1971) & 1 & $+\mathrm{ve}$ \\
\hline & Methyldopa & Burry\&Kirk (1974) & 3 & $2+\mathrm{ve}$ \\
\hline & & & & $1-\mathrm{ve}$ \\
\hline & Methyldopa & Hay\&Reade (1978) & 17 & $8+v e$ \\
\hline & & & & $2-v e$ \\
\hline & & & & 9 no Bx \\
\hline & Methyldopa & Brooks (1982) & 1 & No Bx \\
\hline & Methyldopa & Williams (1983) & 1 & - ve \\
\hline & Oxprenolol & Wiesenfeld et al. (1982) & 1 & + ve \\
\hline & Practolol & Felix et al. (1974) & 1 & Not clear \\
\hline & Propanolol & Hawk (1980) & 1 & $+\mathrm{ve}$ \\
\hline \multirow[t]{10}{*}{ Antimalarials } & Chloroquine & Savage (1958) & 1 & No Bx \\
\hline & Pyrimethamine & Cutler (1980) & 1 & $+\mathrm{ve}$ \\
\hline & Quinacrine & Bagby (1945) & 2 & $+\mathrm{ve}$ \\
\hline & Quinacrine & Nisbet (1945) & Many & Not registered \\
\hline & Quinacrine & Schmitt et al. (1945) & $16 ?$ & Mostly + ve \\
\hline & & & & Some no Bx \\
\hline & Quinacrine & Bazemore et al. (1946) & 150 & None \\
\hline & Quinacrine & Wilson (1946) & $>300$ & Some + ve \\
\hline & & & & Some - ve \\
\hline & Ketoconazole & Markitziu et al (1986) & 8 & Some no Bx? \\
\hline \multirow{5}{*}{ Antimicrobials } & Para-aminosalicylic & MTaIKILZIU et al. (1900) & 0 & $+\mathrm{ve}$ \\
\hline & acid & Shatin et al. (1953) & 2 & $+\mathrm{ve}$ \\
\hline & Tetracycline & Fitzpatrick (1963) & 1 & No Bx \\
\hline & Sulfamethoxazole & Bronny\&Thies (1990) & 1 & Not clear \\
\hline & Fenclofenac & Ferguson et al. (1984) & 1 & $+\mathrm{ve}$ \\
\hline \multirow[t]{7}{*}{ NSAIDs } & Phenylbutazone & Gold (1966) & 1 & + ve \\
\hline & Nonspecific NSAID & Potts et al. (1987) & 27 & Not clear \\
\hline & & & & (Mostly Bx +ve) \\
\hline & & & & Some - ve \\
\hline & Naproxen & Gibson et al. (1986) & 1 & $+\mathrm{ve}$ \\
\hline & Rofecoxib & Bagán et al. (2004) & 3 & No $B x$ \\
\hline & Tolbutamide & Hurlbut (1963) & 1 & No $B x$ \\
\hline Hypoglycemic drugs & Chlorpropamide & Dinsdale et al. (1968) & 1 & $+\mathrm{ve}$ \\
\hline \multirow[t]{6}{*}{ Penicillamine } & Penicillamine & Seehafer et al. (1981) & 6 & $4+$ ve \\
\hline & & & & 2 no Bx \\
\hline & Penicillamine & Powell et al. (1983) & 11 & $7+v e$ \\
\hline & & & & 2 - ve? \\
\hline & & & & 8 no Bx \\
\hline & Penicillamine & Blasberg et al. (1984) & 7 & $+\mathrm{ve}$ \\
\hline ACEIs & Captopril, Enalapril & Firth (1989) & 2 & Not clear \\
\hline \multirow{3}{*}{$\begin{array}{l}\text { Thyrokinase-selective } \\
\text { immuneosuppressors }\end{array}$} & Imatinib & Pascual et al. (2006) & 2 & + ve \\
\hline & Imatinib & Ena et al. (2004) & 1 & $+\mathrm{ve}$ \\
\hline & Imatinib & Lim \& Muir (2002) & 1 & $+\mathrm{ve}$ \\
\hline \multirow[t]{20}{*}{ Miscellaneous } & Allopurinol & Chau et al. (1984) & 3 & $1+\mathrm{ve}$ \\
\hline & & & & 2 no Bx \\
\hline & Amiphenazole & Baker et al. (1964) & 4 & $1+$ ve \\
\hline & & & & 1 - ve \\
\hline & & & & 2 no Bx \\
\hline & Amiphenazole & Dinsdale \& Walker(1966) & 1 & $+\mathrm{ve}$ \\
\hline & Carbamazepine & Roberts \& Marks (1981) & 1 & $+\mathrm{ve}$ \\
\hline & Cyanamide & Torrelo et al. (1990) & 1 & $+\mathrm{ve}$ \\
\hline & Levamisole & Kirby et al. (1980) & 2 & $+\mathrm{ve}$ \\
\hline & Lithium & Hogan et al. (1985) & 1 & $+\mathrm{ve}$ \\
\hline & Lithium & Campisi et al. (2005) & 1 & $+\mathrm{ve}$ \\
\hline & Lorazepam & Colvard et al. (1986) & 1 & - ve \\
\hline & Escitalopram & Aframian (2007) & 1 & No $B x$ \\
\hline & Methopromazine & Groth (1961) & 1 & $+\mathrm{ve}$ \\
\hline & Pyritinol & Ishibashi et al. (1973) & 1 & $+\mathrm{ve}$ \\
\hline & Clopidrogel & Guijarro (2003) & 1 & $+\mathrm{ve}$ \\
\hline & Adalimumab & Simone et al. (2008) & 1 & $+\mathrm{ve}$ \\
\hline & Hepatitis B vaccine & Pemberton (2000) & 1 & $+\mathrm{ve}$ \\
\hline & $\begin{array}{l}\text { Interferon-alpha } 2 \mathrm{a}, \\
\text { rivavicin, propanolol }\end{array}$ & Armour \& Lowe (2005) & 1 & + ve \\
\hline & $\begin{array}{l}\text { Interferon-alpha, ri- } \\
\text { vavicin }\end{array}$ & Giuliani (2008) & 2 & + ve \\
\hline
\end{tabular}

Table 1. Drugs reported in the literature as being related to oral lichenoid reactions. Expanded from the study of McCartan and McCreary (4) published in 1997 (Abbreviations: Bx = biopsy; +ve = positive; -ve = negative; ACEIs= angiotensin-converting enzyme inhibitors; NSAIDs = Nonsteroidal anti-inflammatory drugs). 


\section{Concept}

The terms oral lichenoid reactions (OLRs) or oral lichenoid lesions (OLLs) refer to lesions histologically and clinically similar to oral lichen planus (OLP), though with the particularity that in these cases the underlying cause is identifiable (1).

The literature uses a range of different terms in reference to lesions of this kind (2). Most of the publications refer to them according to the causal factor involved, including alterations resulting from direct contact with dental restoration materials, drug-related lesions, and lesions associated to graft-versus-host disease $(1,2)$.

Drug-induced oral lichenoid reactions were first mentioned in 1929, and were later cited in 1971 by Almeyda and Levantine (3). Many cases were documented among United States military personnel during the war in the Pacific, southeastern Europe and Indonesia. The mentioned authors reported an apparent relationship between the clinical findings in these individuals and the prophylactic use of antimalarial drugs. Since then, many drug substances have been associated with such lesions (4).

\section{Epidemiology}

The precise epidemiological characteristics of these lesions are difficult to establish, due to the diverse and imprecise terminology used in establishing a final diagnosis of lichen planus (LP) as "probable", "possible" or "suggestive", in those situations where the histopathological and clinical findings are less clear than in classical lichen planus (2). In addition, the absence of histological confirmation in most of the articles published on OLPrelated disorders makes it difficult to establish their true prevalence or incidence (5).

Nevertheless, it is believed that the prevalence of OLRs attributable to drug substances is increasing. According to some authors (6), newly marketed drugs that are generally used among the population, such as antihypertensive agents, can cause such lesions as side effects. In contrast, other investigators point to increased experience and awareness among the different health professionals (dentists as well as dermatologists) as the factor contributing to improved differentiation of the broad range of disorders related to lichen planus.

\section{Etiopthogenesis}

The etiopathogenic mechanism by which these lesions are produced is not known. The literature has identified a series of triggering factors, such as dental restoration materials, graft-versus-host disease, and a broad range of drugs $(6,7)$.

A great many materials commonly used in restoration treatments in the oral cavity have been identified as triggering elements, including silver amalgam, gold, cobalt, palladium, chromium and even non-metals such as epoxy resins (composite) $(1,7,8)$.

Bäckman and Jontell (9) in turn have pointed to dental material coadjuvants such as dental tartar deposited upon the materials, oral breathing and hyposialia as etiological factors. These authors published the case of a patient with all three factors who developed a lichenoid reaction in the absence of dental restoration.

On the other hand, many drug substances are reportedly able to produce such reactions (Table 1). The most commonly implicated agents are nonsteroidal antiinflammatory drugs and angiotensin converting enzyme inhibitors $(10,11)$.

In many cases these drugs are used in combination - thus suggesting the possible existence of synergic effects between them. Some authors consider it quite likely that the so-called "Grinspan syndrome", in which oral lichen planus is related to diabetes mellitus and arterial hypertension, is in fact simply an example of oral lichenoid reaction induced by the drugs simultaneously used to treat the latter two diseases (12).

\section{Clinical manifestations}

The clinical manifestations of oral lichenoid lesions (Fig. 1) are indistinguishable from those of oral lichen planus (7) - with mainly erythematous erosive lesions and an important ulcerative component. All these lesions are characterized by the presence of whitish streaks known as Wickham striae, similar to those seen in lichen planus (13). However, a very significant distinguishing factor with respect to OLP is their atypical location, and particularly the absence of bilaterality of the manifestations $(2-6,9,13)$.

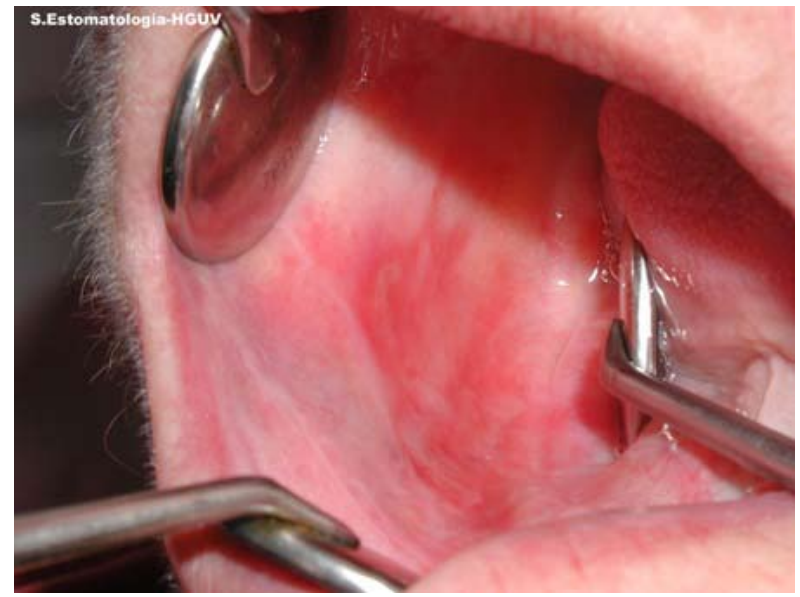

Fig. 1. Image of a unilateral lichenoid reaction affecting the right cheek mucosa in a patient subjected to antihypertensive drug treatment.

In relation to drug-induced lichenoid reactions, no specific clinical features have been described capable of firmly differentiating them from lichenoid reactions caused by other factors. The only clue in this sense is an antecedent of recent or chronic exposure to some drug 


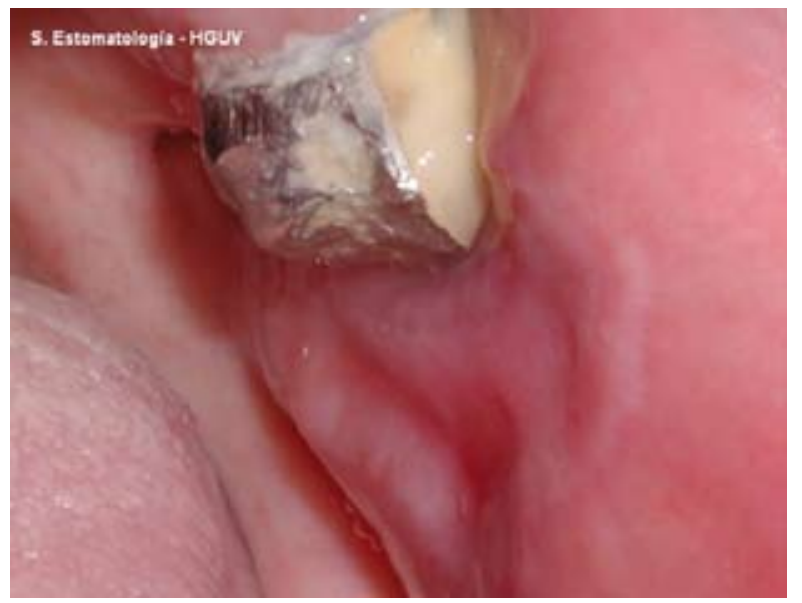

Fig. 2. Image of a unilateral lichenoid reaction affecting the left cheek mucosa in direct relation to a ceramometallic crown.

substance. As a result, a differential diagnosis must be established, considering cases associated to the use of dental materials (Fig. 2), where the lesions are found in contact with or very close to the restorative materials, and confirming that the patient has no antecedents of graft-versus-host disease $(6,7,14)$.

\section{Diagnosis}

The diagnosis of OLRs is based on their clinical charac- teristics and the histological findings $(9,15)$. However, the sensitivity and specificity of histological diagnosis are very low (4). In addition, no definitive molecular diagnostic markers have been established to date (16). Van der Meij et al. (6) have proposed a modification of the diagnostic criteria of the World Health Organization for oral lichen planus and lichenoid reactions (Table 2). As these are cause - effect lesions, the most precise diagnostic clue is determination of whether or not the lesions disappear after eliminating exposure to the suspect etiological factor (8).

However, in the case of drug-induced lesions, suspension of the medication may place patient health at risk (13). Furthermore, in many cases such measures are not useful and reliable as a diagnostic strategy, since the lesions may take months in resolving after suspending the suspect medication $(3,17)$.

\section{Treatment}

The management of such lesions first requires identification of the triggering factor, and the elimination of exposure to it.

In the case of drug-induced OLRs, due evaluation of the risk / benefit ratio of suspending the medication is required. As has been commented, even if the causal medication can be suspended, the lesions may take several

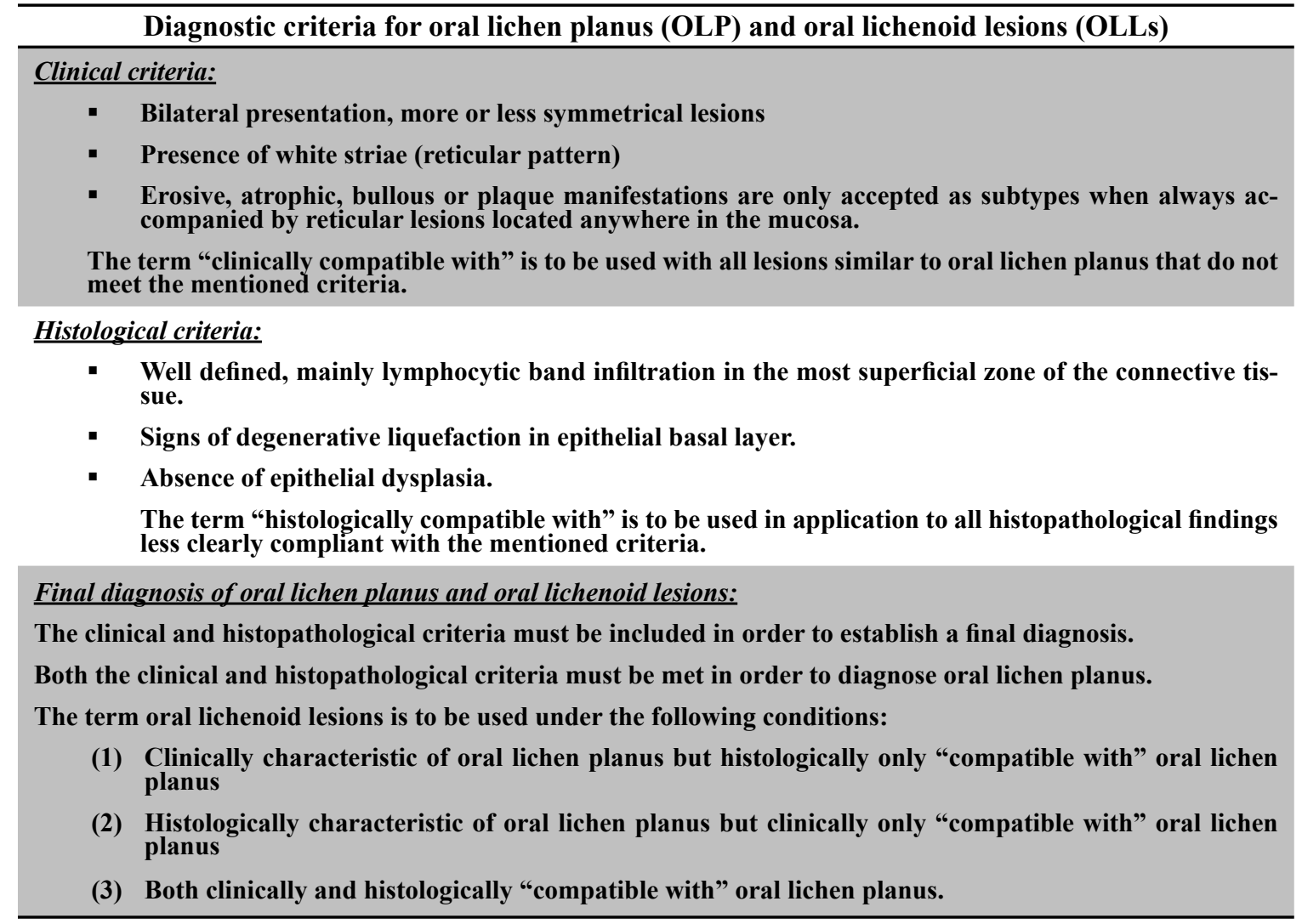

Table 2. Modified World Health Organization criteria for the diagnosis of oral lichenoid reactions (OLRs), oral lichenoid lesions (OLLs) and oral lichen planus (OLP). Van de Meij et al. (6), 2007. 
months in improving. In addition, the pharmacological treatment of OLRs is often not feasible, because the long list of agents capable of causing such lesions includes many substances used to inhibit autoimmune $T$ lymphocytes responses. These drugs are commonly used to treat very severe forms of lichen planus in its atrophic - erosive presentation, and in particular include dapsone, levamisole, tetracyclines and interferon $(18,19)$.

\section{References}

1. Scully C, Carrozzo M. Oral mucosal disease: Lichen planus. Br J Oral Maxillofac Surg.2008;46:15-21.

2. Myers SL, Rhodus NL, Parsons HM, Hodges JS, Kaimal S. A retrospective survey of oral lichenoid lesions: revisiting the diagnostic process for oral lichen planus. Oral Surg Oral Med Oral Pathol Oral Radiol Endod. 2002;93:676-81

3. Almeyda J, Levantine A. Drug reactions. XVI. Lichenoid drug eruptions. Br J Dermatol. 1971;85:604-7.

4. McCartan BE, McCreary CE. Oral lichenoid drug eruptions. Oral Dis. 1997;3:58-63.

5. Myers SL, Rhodus NL, Parsons HM, Hodges JS, Kaimal S. A retrospective survey of oral lichenoid lesions: revisiting the diagnostic process for oral lichen planus. Oral Surg Oral Med Oral Pathol Oral Radiol Endod. 2002 ;93:676-81.

6. Van der Meij EH, Mast H, van der Waal I. The possible premalignant character of oral lichen planus and oral lichenoid lesions: a prospective five-year follow-up study of 192 patients. Oral Oncol. 2007;43:742-8. 7. Issa Y, Brunton PA, Glenny AM, Duxbury AJ. Healing of oral lichenoid lesions after replacing amalgam restorations: a systematic review. Oral Surg Oral Med Oral Pathol Oral Radiol Endod. 2004;98:553-65.

8. Scully C, Carrozzo M. Oral mucosal disease: Lichen planus. Br J Oral Maxillofac Surg. 2008;46:15-21.

9. Bäckman K, Jontell M. Microbial-associated oral lichenoid reactions. Oral Dis. 2007;13:402-6.

10. Scully C, Bagan JV.Adverse drug reactions in the orofacial region. Crit Rev Oral Biol Med. 2004;15:221-39.

11. Bagán JV, Thongprasom K, Scully C. Adverse oral reactions associated with the COX-2 inhibitor rofecoxib.Oral Dis. 2004;10:401-3. 12. Aljabre SH. Grinspan's syndrome. J Am Acad Dermatol. 1994;30:671.

13. DeRossi SS, Ciarrocca KN. Lichen planus, lichenoid drug reactions, and lichenoid mucositis. Dent Clin North Am. 2005;49:77-89.

14. De la Rosa-García E, Bologna-Molina R, Vega-González MTJ. Graft-versus-host disease, an eight case report and literature review. Med Oral Patol Oral Cir Bucal 2006;11:E486-92.

15. Cobos-Fuentes MJ, Martínez-Sahuquillo-Márquez A, GallardoCastillo I, Armas-Padrón JR, Moreno-Fernández A, Bullón-Fernández P. Oral lichenoid lesions related to contact with dental materials: a literature review. Med Oral Patol Oral Cir Bucal. 2009;14:e514-20.

16. Segura-Egea JJ, Bullón-Fernández P. Lichenoid reaction associated to amalgam restoration. Med Oral Patol Oral Cir Bucal. 2004;9:423-4; 421-3.

17. Pereira CM, de Almeida OP, Correa ME, Souza CA, Barjas-Castro ML.Oral involvement in chronic graft versus host disease: a prospective study of 19 Brazilian patients. Gen Dent. 2007;55:48-51.

18. Al-Hashimi I, Schifter M, Lockhart PB, Wray D, Brennan M, Migliorati CA, et al. Oral lichen planus and oral lichenoid lesions: diagnostic and therapeutic considerations. Oral Surg Oral Med Oral Pathol Oral Radiol Endod. 2007;103:S25.e1-12.

19. Scully C, Bagan JV. Adverse drug reactions in the orofacial region. Crit Rev Oral Biol Med. 2004;15:221-39. 